\title{
Cytotoxicity of RNase Sa to the acute myeloid leukemia Kasumi-1 cells depends on the net charge
}

\author{
Vladimir A. Mitkevich ${ }^{1}$, Ksenia M. Burnysheva ${ }^{1}$, Olga N. Ilinskaya ${ }^{1,2}$, C. Nick Pace ${ }^{3,4}$ \\ and Alexander A. Makarov ${ }^{1}$ \\ ${ }^{1}$ Engelhardt Institute of Molecular Biology, Russian Academy of Sciences, Moscow, Russia \\ ${ }^{2}$ Department of Microbiology, Kazan Federal (Volga-Region) University, Kazan, Russia \\ ${ }^{3}$ Department of Biochemistry and Biophysics, Texas A\&M University, College Station, Texas, USA \\ ${ }^{4}$ Department of Molecular and Cellular Medicine, Texas A\&M Health Science Center, Texas A\&M University, College Station, \\ Texas, USA \\ Correspondence to: Alexander A. Makarov, email: aamakarov@eimb.ru
}

Keywords: RNase; cytotoxicity; net charge; cationization; N-terminus; apoptosis

Received: October 24, $2014 \quad$ Accepted: Novemeber 10, $2014 \quad$ Published: November 10, 2014

This is an open-access article distributed under the terms of the Creative Commons Attribution License, which permits unrestricted use, distribution, and reproduction in any medium, provided the original author and source are credited.

\section{ABSTRACT}

The majority of known cytotoxic RNases are basic proteins which destroy intracellular RNA. Cationization of RNases is considered to be an effective strategy for strengthening their antitumor properties. We constructed a set of RNase Sa variants consisting of charge reversal mutants, charge neutralization mutants, and variants with positively charged cluster at the $\mathbf{N}$-terminus. All constructs retain a high level of catalytic activity and differ in net charge. Using acute myeloid leukemia cells Kasumi-1 we have shown that (i) cytotoxicity of RNase Sa mutants is linearly enhanced by cationization, (ii) the ability of cytotoxic mutants to induce cell death is caused by induction of apoptosis and (iii) localization of positive charge on $\mathrm{N}$-terminus does not contribute to RNase Sa cytotoxicity. Capacity to induce apoptosis in malignant cells and the absence of necrotic effects make the RNase Sa mutants with high positive charge a suitable anti-cancer agent.

\section{INTRODUCTION}

Some RNases selectively attack malignant cells, triggering apoptotic response [1-3]. Their selectivity for transformed cells is in part based on the positive charge of the enzyme, which allows it to bind anionic groups on the surface of tumor cells [1]. Tumor cells express more acidic phospholipids on the outer leaflet of their membrane than their non-tumor counterparts, and therefore are more negatively charged [4]. Most cytotoxic RNases are cationic [5]. Thus, cationization of RNases can be a promising way to enhance their antitumor effect [6]. Addition of positive charge to the variants of RNase A engineered to evade the endogenous ribonuclease inhibitor protein facilitates their entry into the cytosol, and thus increases their cytotoxicity [7]. We have previously shown that reversing five charges on the RNase from Streptomyces aureofaciens (RNase Sa) was sufficient to change it from one of the most acidic proteins $(\mathrm{pI}=3.5)$ to one of the most basic proteins $(5 \mathrm{~K}$ $\mathrm{Sa}$ ), and to turn a non-cytotoxic RNase into a cytotoxic one $[8,9]$. However, a significant increase of the basicity of RNases could have the deleterious consequence of decreasing ribonucleolytic activity or conformational stability, which may adversely affect the cytotoxicity of the enzyme [7]. It is not clear exactly how the positive charge must be distributed over the surface of an RNase molecule for its cytotoxic properties to be optimal. For example, among 22 variants of onconase in which cationic residues were replaced with alanine it was found that a more basic variant could be either markedly more cytotoxic or less cytotoxic than a less cationic variant, depending on the distribution of its cationic residues [10].

To explore a possibility of further enhancing the cytotoxicity of RNase Sa we have constructed mutants $6 \mathrm{~K}$ and $7 \mathrm{~K}$, carrying higher positive charges in comparison with $5 \mathrm{~K}$ mutant (Table 1). All replaced residues were exposed to solvent and did not form ion pairs or hydrogen bonds. The charge neutralization mutants $3 \mathrm{NQ}$ and $5 \mathrm{NQ}$ were also constructed in order to ascertain the role of negative charge in cytotoxicity (Table 1). In these 
mutants the surface residues Glu and Asp, which were already replaced with lysines in the $3 \mathrm{~K}$ and $5 \mathrm{~K}$ mutants, have been now replaced with Gln and Asn respectively. In order to test if the net charge per se is responsible for the enzyme ability to attack mammalian cells or whether the distribution of charges is important as well, we have compared cytotoxicity of the RNase $\mathrm{Sa} 5 \mathrm{~K}$ and $5 \mathrm{NQ}$ mutants with cytotoxicity of their variants featuring additional two Lys residues tagged to the N-terminus (Table 1). Using human acute myeloid leukemia cells Kasumi-1 we have shown that (i) cytotoxicity of RNase Sa mutants is linearly enhanced by cationization, (ii) the ability of cytotoxic mutants to induce cell death is caused by induction of apoptosis and (iii) localization of positive charge on N-terminus does not contribute to RNase Sa cytotoxicity.

\section{RESULTS}

\section{Catalytic activity of RNase Sa mutants}

Catalytic activity of RNase $\mathrm{Sa}$ mutants was determined using poly(I) as a substrate (Table 2). The greatest decrease in activity was detected for the $5 \mathrm{~K} \mathrm{Sa}$ and $\mathrm{K}_{2}{ }^{\mathrm{N}} 5 \mathrm{~K} \mathrm{Sa}$, which resulted to be $14 \%$ and $17 \%$ of the activity of the wild type enzyme, respectively. The variants $5 \mathrm{NQ}$ Sa and $\mathrm{K}_{2}{ }^{\mathrm{N}} 5 \mathrm{NQ}$ Sa operate at a half of the wild type catalytic activity. The activity of all other variants is close to the activity of the wild type enzyme.

\section{Cytotoxicity of the surface charge reversal and charge neutralization mutants of RNase Sa}

To study cytotoxicity of the RNase Sa variants we used human acute myeloid leukemia cells Kasumi-1. We had earlier shown that these cells are highly sensitive to the toxic effect of a RNase Sa homolog binase ( $\mathrm{pI}=9.5$ ), the basic RNase from Bacillus intermedius [11, 12]. RNase Sa has very limited toxic effect on the Kasumi-1 cells, and at the $10 \mu \mathrm{M}$ concentration reduces cell viability only to $84 \%$ (Fig. 1). In the group of mutants with net charges varying from -4 (3NQ Sa) up to +6 in the $7 \mathrm{~K} \mathrm{Sa}$ (Table 1), $7 \mathrm{~K} \mathrm{Sa}$ showed the highest cytotoxic effect reducing cell viability to $4 \%$ at the $10 \mu \mathrm{M}$ concentration (Fig. 1). Concentration-response relationships (Fig. 1A) revealed $\mathrm{IC}_{50}$ (RNase concentration that kills $50 \%$ of cells) of $6 \pm 1$ $\mu \mathrm{M}$ for the $5 \mathrm{~K} \mathrm{Sa}$ and $2 \pm 0.5 \mu \mathrm{M}$ for the $6 \mathrm{~K}$ and $7 \mathrm{~K} \mathrm{Sa}$.

In the $3 \mathrm{NQ}$ and $5 \mathrm{NQ}$ RNase Sa mutants, the amino acid residues have been replaced with neutral asparagine and glutamine in the same positions as in the $3 \mathrm{~K}$ Sa and $5 \mathrm{~K} \mathrm{Sa}$. This resulted in only partial neutralization of the initial negative charge of the RNase molecule (Table 1). The cytotoxicity of these mutants, still rather negatively charged (-4 for 3NQ Sa and -2 for 5NQ Sa), практически не отличалась от wild type RNase Sa (Fig. 1A). These results show that a nearly neutral $(3 \mathrm{~K} \mathrm{Sa})$ or a positive net charge is a prerequisite for the RNase cytotoxicity, and that the increase of positive charge on the RNase molecule linearly correlates with the enhancement of enzyme cytotoxicity (correlation coefficient, $\mathrm{R}=0.97$ ). This correlation is demonstrated in Fig. 1B.

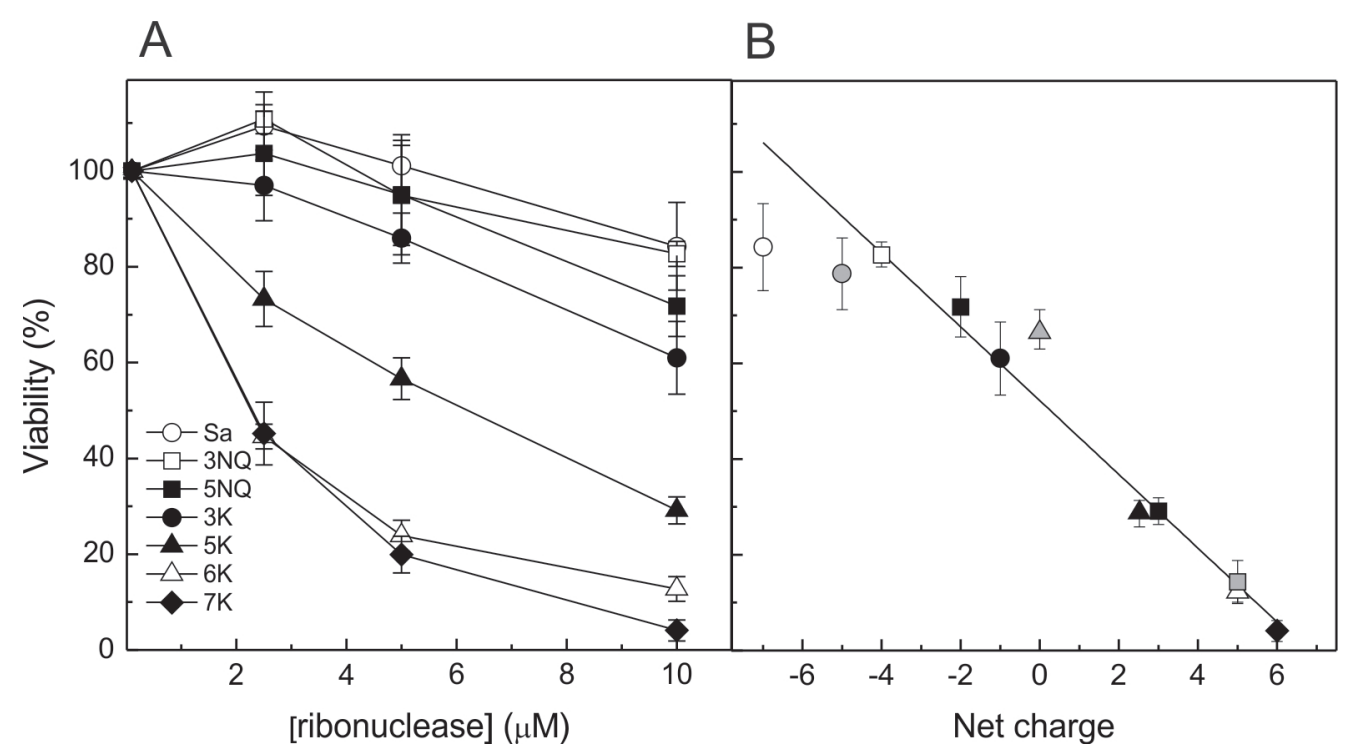

Figure 1: Cytotoxicity of RNase Sa and its charge reversed mutants on Kasumi-1 cells. (A) Viability of Kasumi-1 cells

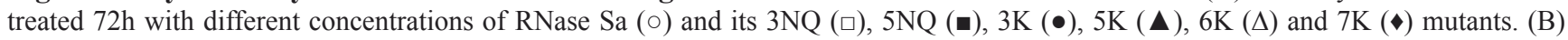
Viability of Kasumi-1 cells treated $72 \mathrm{~h}$ with $10 \mu \mathrm{M}$ RNases (as specified in (A) and in Fig. 3A for $\mathrm{K}_{2}{ }^{\mathrm{N} S a}$, $\mathrm{K}_{2}^{\mathrm{N}} 5 \mathrm{NQ}$ Sa and $\mathrm{K}_{2}^{\mathrm{N}} 5 \mathrm{~K}$ Sa) versus net charge on the enzymes at $\mathrm{pH}$ 7. This dependence can be approximated by a linear curve with the correlation coefficient $\mathrm{R}=0.97$. Each value is the mean of three independent experiments with triplicate samples $\pm \mathrm{SD}$ and is expressed as a percentage of the value obtained for the control lacking RNase. 
Table 1: Net charge and $\mathrm{pI}$ for the surface charge reversal and charge neutralization mutants, and the $\mathrm{N}$-terminal Lys-tagged variants of RNase Sa

\begin{tabular}{|c|c|c|c|}
\hline Protein variant & Description & $\begin{array}{l}\text { Net charge at } \\
\mathrm{pH} 7^{\mathrm{a}}\end{array}$ & $\mathrm{pI}^{\mathrm{b}}$ \\
\hline Wild type & & -1 & 3.5 \\
\hline \multicolumn{4}{|c|}{ Charge reversal mutants } \\
\hline $3 \mathrm{~K} \mathrm{Sa}$ & D1K, D17K, E41K & -1 & 6.4 \\
\hline $5 \mathrm{~K} \mathrm{Sa}$ & $3 \mathrm{~K} \mathrm{Sa}+\mathrm{D} 25 \mathrm{~K}, \mathrm{E} 74 \mathrm{~K}$ & +3 & 10.2 \\
\hline $6 \mathrm{~K} \mathrm{Sa}$ & $5 \mathrm{~K} \mathrm{Sa}+\mathrm{D} 79 \mathrm{~K}$ & +5 & $>10.5$ \\
\hline $7 \mathrm{~K} \mathrm{Sa}$ & $6 \mathrm{~K} \mathrm{Sa}+\mathrm{S} 31 \mathrm{~K}$ & +6 & $>10.5$ \\
\hline \multicolumn{4}{|c|}{ Charge neutralization mutants } \\
\hline $3 \mathrm{NQ} \mathrm{Sa}$ & D1N, D17N, E41Q & -4 & 4.5 \\
\hline $5 \mathrm{NQ} \mathrm{Sa}$ & $3 \mathrm{NQ} \mathrm{Sa}+\mathrm{D} 25 \mathrm{~N}, \mathrm{E} 74 \mathrm{Q}$ & -2 & 5.7 \\
\hline \multicolumn{4}{|c|}{ N-terminal extension variants } \\
\hline $\mathrm{K}_{2}{ }^{\mathrm{N}} \mathrm{Sa}$ & 2K tagged to N-terminus of $\mathrm{Sa}$ & -5 & 4.9 \\
\hline $\mathrm{K}_{2}{ }^{\mathrm{N}} 5 \mathrm{NQ} \mathrm{Sa}$ & $2 \mathrm{~K}$ tagged to $\mathrm{N}$-terminus of $5 \mathrm{NQ} \mathrm{Sa}$ & 0 & 8.8 \\
\hline $\mathrm{K}_{2}{ }^{\mathrm{N}} 5 \mathrm{~K} \mathrm{Sa}$ & 2 Lys tagged to $\mathrm{N}$-terminus of $5 \mathrm{~K} \mathrm{Sa}$ & +5 & $>10.4$ \\
\hline
\end{tabular}

a The net charge at $\mathrm{pH} 7$ is calculated for each variant applying model compound $\mathrm{pK}$ values for each ionizable residue.

$\mathrm{b}$ The $\mathrm{pI}$ values are estimates, except for the wild type, $3 \mathrm{~K}$ and $5 \mathrm{~K}$, where $\mathrm{pI}$ have been measured [24].

Table 2: Kinetic parameters characterizing the cleavage of poly(I) by RNase Sa and its variants at $25^{\circ} \mathrm{C}$ and pH 6.5 (0.05 M Tris, 0.05 M NaAc, 0.1 M NaCl)

\begin{tabular}{|l|l|l|l|l|}
\hline RNase & $\mathrm{k}_{\text {cat }}\left(\mathrm{s}^{-1}\right)$ & $\mathrm{K}_{\mathrm{M}} \times 10^{4}(\mathrm{M})$ & $\mathrm{k}_{\text {cat }} / \mathrm{K}_{\mathrm{M}} \times 10^{-4}\left(\mathrm{M}^{-1} \mathrm{~s}^{-1}\right)$ & ${\text { Catalytic activity }(\%)^{\mathrm{a}}}$ \\
& & & & \\
\hline Wild type & $221 \pm 13$ & $1.6 \pm 0.2$ & 138 & 100 \\
\hline 3NQ Sa & $172 \pm 12$ & $1.7 \pm 0.2$ & 101 & 73 \\
\hline $5 \mathrm{NQ} \mathrm{Sa}$ & $93 \pm 8$ & $1.6 \pm 0.2$ & 58 & 42 \\
\hline 3K Sa & $150 \pm 11$ & $1.4 \pm 0.2$ & 107 & 78 \\
\hline $5 \mathrm{~K} \mathrm{Sa}$ & $25 \pm 3$ & $1.3 \pm 0.2$ & 19 & 14 \\
\hline $6 \mathrm{~K} \mathrm{Sa}$ & $168 \pm 12$ & $1.4 \pm 0.2$ & 120 & 87 \\
\hline $7 \mathrm{~K} \mathrm{Sa}$ & $163 \pm 12$ & $1.3 \pm 0.2$ & 125 & 91 \\
\hline $\mathrm{K}_{2}{ }^{\mathrm{N}} \mathrm{Sa}$ & $238 \pm 18$ & $1.7 \pm 0.2$ & 140 & 101 \\
\hline $\mathrm{K}_{2}{ }^{\mathrm{N}} 5 \mathrm{NQ} \mathrm{Sa}$ & $120 \pm 10$ & $1.6 \pm 0.2$ & 75 & 54 \\
\hline $\mathrm{K}_{2}{ }^{\mathrm{N}} 5 \mathrm{Ka}$ & $36 \pm 3$ & $1.5 \pm 0.2$ & 24 & 17 \\
\hline
\end{tabular}

${ }^{\text {a }}$ Catalytic activity of RNase Sa was taken as $100 \%$.

Using flow cytometry we have found that cytotoxic effect of RNase Sa and its mutants on Kasumi-1 cells is caused by apoptosis (Fig. 2A), with the ratio of necrotic cells in the population not above $2 \%$. Proportion of apoptotic cells in the population treated by the RNases under study displayed linear growth with increasing positive charge on the protein molecule $(\mathrm{R}=0.92)$ and at $10 \mu \mathrm{M}$ for the mutants $5 \mathrm{~K}, 6 \mathrm{~K}$ and $7 \mathrm{~K}$ reached $46 \%, 65 \%$ and $76 \%$, respectively (Fig. $2 \mathrm{~B}$ ).

\section{Cytotoxicity of the N-terminal Lys-tagged variants of RNase Sa}

We addressed the question of whether the location of positive charge might also affect cytotoxicity.
Therefore we constructed variants with positively charged $\mathrm{N}$-terminal extension groups, based on the initially nontoxic wild type RNase $\mathrm{Sa}$ and 5NQ $\mathrm{Sa}$, and the cytotoxic $5 \mathrm{~K} \mathrm{Sa}$ (Table 1). Variants $\mathrm{K}_{2}{ }^{\mathrm{N}} \mathrm{Sa}$ and $\mathrm{K}_{2}{ }^{\mathrm{N}} 5 \mathrm{NQ}$ Sa did not exhibited enhanced cytotoxicity or apoptogenic activity compared to their corresponding initial forms (Figs. $1,3)$. Cytotoxic properties of $\mathrm{K}_{2}{ }^{\mathrm{N}} 5 \mathrm{~K}$ Sa were higher in comparison with $5 \mathrm{~K} \mathrm{Sa}$ - the Kasumi-1 cell survival rate decreased faster, and the percentage of apoptotic cells in the population showed statistically significant increase (Fig. 3A,B). However cytotoxic properties of the $\mathrm{K}_{2}{ }^{\mathrm{N}} 5 \mathrm{~K}$ $\mathrm{Sa}$ are somewhat less prominent than that of the $6 \mathrm{~K}$ mutant characterized by the same net charge $(+5): \mathrm{IC}_{50}=4 \pm 1 \mu \mathrm{M}$ vs $2 \pm 0.5 \mu \mathrm{M}$, and at $10 \mu \mathrm{M}$ the percentage of apoptotic cells in the population reached $60.9 \pm 3.2$ vs $64.9 \pm 0.6$. Despite this, cytotoxicity of Lys-tagged mutants fit to a 
linear dependence from the charge on molecule (Fig. 1B).

\section{DISCUSSION}

Enzymatic catalysis provides an extremely sensitive measure of native protein structure [13]. The fact that all of the RNase Sa variants have substantial catalytic activity (Table 2) suggests that their conformations are similar to that of the wild type enzyme. Decrease in activity of the $5 \mathrm{~K} \mathrm{Sa}$ and $\mathrm{K}_{2}{ }^{\mathrm{N}} 5 \mathrm{~K}$ Sa to $14 \%$ and $17 \%$, respectively, is due to the Glu74Lys substitution that changes the orientation of the enzyme catalytic groups [14]. However, activity of $6 \mathrm{~K}$ Sa and 7K Sa, also containing the Glu74Lys substitution, is close to the activity of the wild type enzyme (Table 2). Evidently, this effect is caused by the additional Asp79Lys substitution (Table 1). Activity of the Asp79Lys mutant is equal to that of the wild type Sa, although this substitution essentially influences thermal stability of the enzyme by increasing its melting temperature by $7.6^{\circ} \mathrm{C}$ [15]. It may be possible that stabilization of conformational mobility of the Asp79 environment upon its replacement with Lys eliminates the effect of conformational disturbances on the

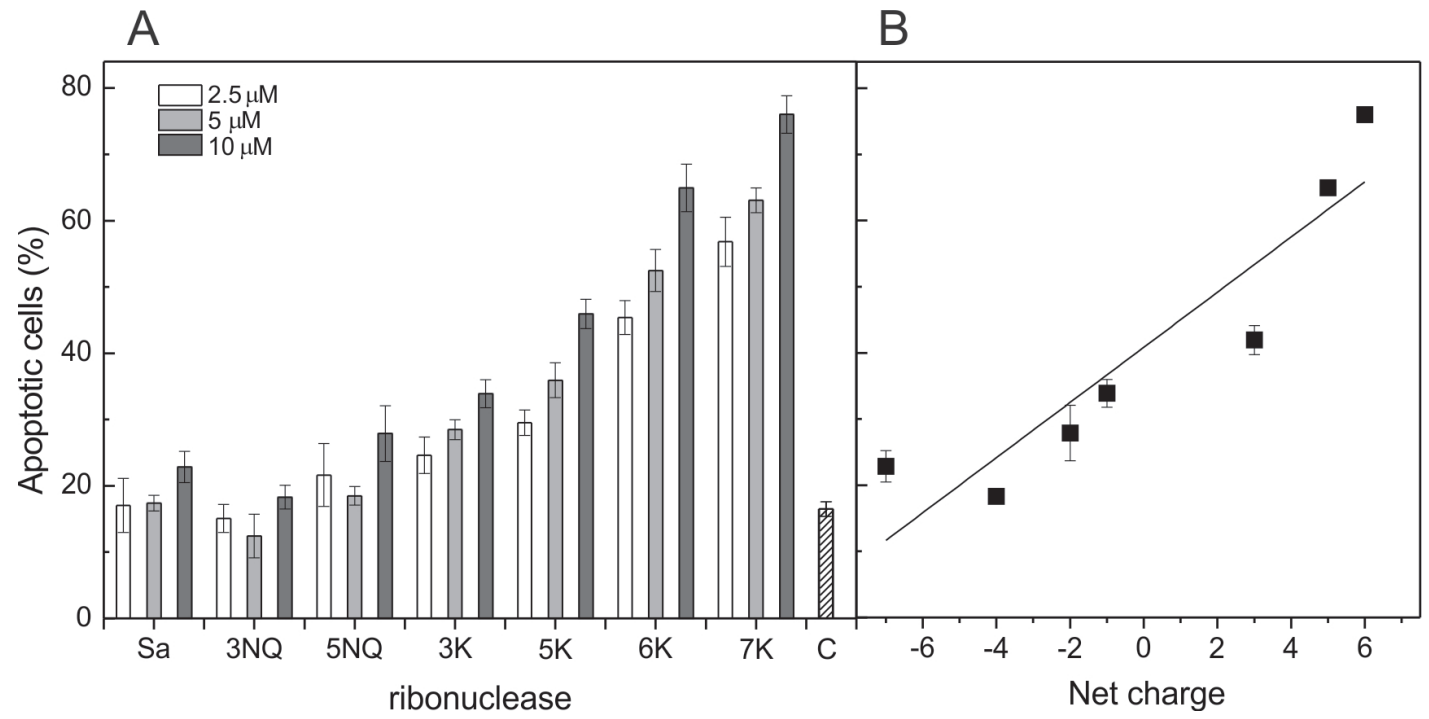

Figure 2: Apoptotic activity of RNase Sa and its charge reversed mutants on Kasumi-1 cells. (A) Influence of RNase Sa and its mutants treatment $(72 \mathrm{~h}$ ) on the amount of apoptotic cells of Kasumi-1 cells. White columns - $2.5 \mu \mathrm{M}$ RNase, light gray columns $-5 \mu \mathrm{M}$ RNase and dark gray columns - $10 \mu \mathrm{M}$ RNase. Dashed column (C) - level of apoptotic cells in the control lacking RNase. (B) The amount of apoptotic cells of Kasumi-1 cells treated $72 \mathrm{~h}$ with $10 \mu \mathrm{M}$ RNases versus net charge on the enzymes at $\mathrm{pH}$ 7. This dependence can be approximated by a linear curve with the correlation coefficient $\mathrm{R}=0.92$. The amount of apoptotic cells is expressed as a percentage of the total number of cells for each variant. Each value is the mean of three independent experiments with triplicate samples $\pm \mathrm{SD}$.
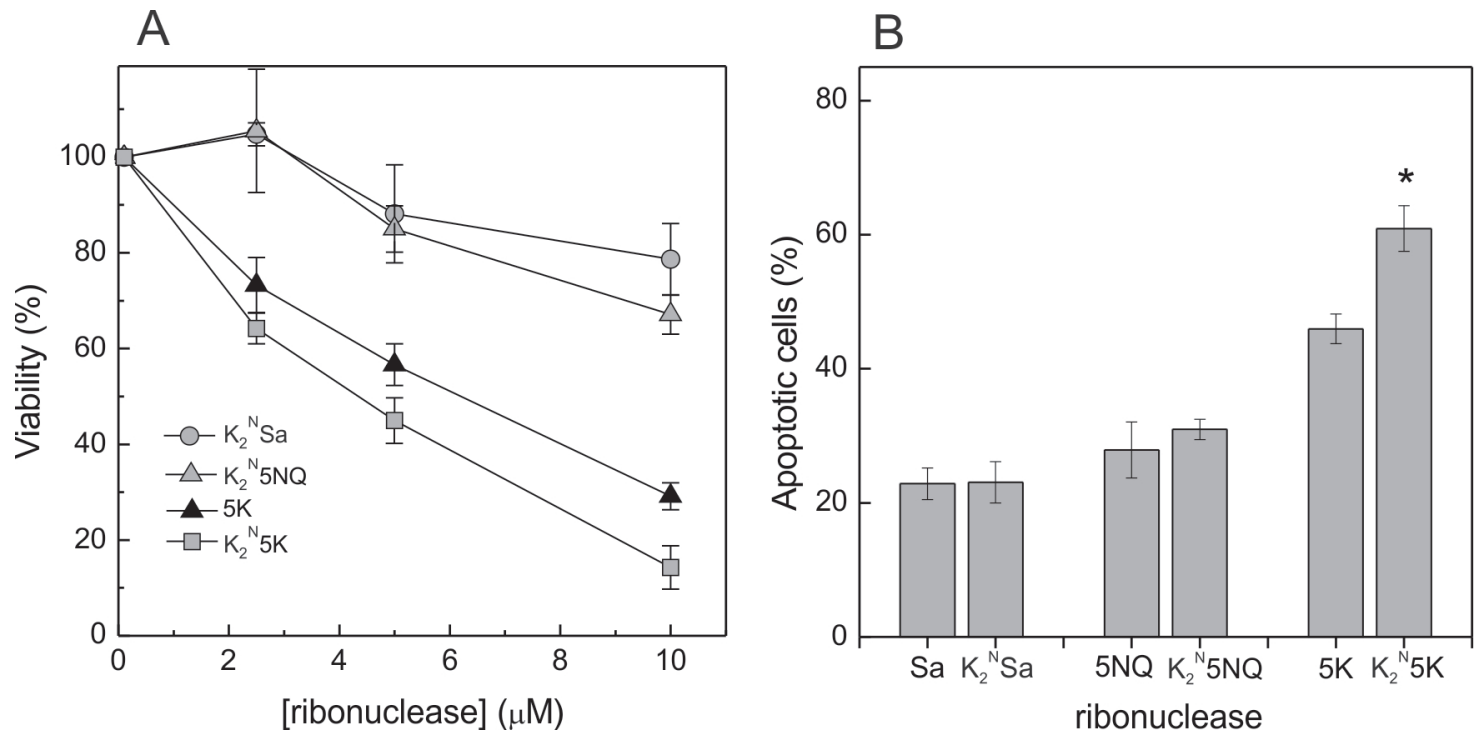

Figure 3: Cytotoxicity and apoptotic activity of the N-terminal Lys-tagged variants of RNase Sa. (A) Viability of Kasumi-1 cells treated $72 \mathrm{~h}$ with different concentrations of $5 \mathrm{~K}$ RNase $\mathrm{Sa}(\boldsymbol{\Lambda}), \mathrm{K}_{2}{ }^{\mathrm{N}} \mathrm{Sa}(\mathrm{O}), \mathrm{K}_{2}{ }^{\mathrm{N}} 5 \mathrm{NQ} \mathrm{Sa}(\triangle)$ and $\mathrm{K}_{2}{ }^{\mathrm{N}} 5 \mathrm{~K}$ Sa $(\square)$. (B) Influence of 10 $\mu \mathrm{M}$ RNase Sa, $5 \mathrm{NQ}$ and $5 \mathrm{~K}$ and their Lys-tagged variants $\left(\mathrm{K}_{2}{ }^{\mathrm{N}} \mathrm{Sa}, \mathrm{K}_{2}{ }^{\mathrm{N}} 5 \mathrm{NQ}\right.$ Sa and $\mathrm{K}_{2}{ }^{\mathrm{N}} 5 \mathrm{~K}$ Sa) on the amount of apoptotic cells of Kasumi-1 cells. Each value is the mean of three independent experiments with triplicate samples $\pm \mathrm{SD} ; * \mathrm{p}<0.005$. 
active center caused by the Glu74Lys substitution.

The addition of a 2 Lys tag appears to have little effect on the three-dimensional structure of wild-type RNase Sa and its $5 \mathrm{NQ}$ and $5 \mathrm{~K}$ variants, based on the absence of change in the values of $\mathrm{kcat} / \mathrm{K}_{\mathrm{M}}$ for poly(I) cleavage (Table 2).

Negative surface charge of eukaryotic and bacterial cells causes their preferential interaction with cationic RNase. Membrane of tumor cells comprises more acidic phospholipids and glycoproteins compared to normal cells [16]. Cytotoxicity of the chemically modified RNase A correlates with the positive charge, reaching its limit at high values of positive charge on the molecule $[17,18]$. We demonstrated earlier that the site-specific mutagenesis of the non-toxic acidic RNase Sa can be used to obtain a highly cytotoxic enzyme (5K Sa) [8]. In this work we have constructed $6 \mathrm{~K}$ and $7 \mathrm{~K}$ mutants of RNase $\mathrm{Sa}$, in which positive net charge has been incremented to +5 and +6 (Table 1). The cytotoxicity of these mutants increased in comparison with the $5 \mathrm{~K}$ mutant (Fig. 1). Moreover we have shown that cytotoxic properties of RNase depend linearly on its net charge (Figs. 1B and 2B). The higher was positive charge acquired by the enzyme molecule the stronger it affected cell survival rate and apoptosis. This might be important for possible application of such RNases in tumor therapy, as it would exclude adverse effects from cell death by the necrosis path.

Ostensibly, not only the net charge but its localization on the molecule contributes to the cytotoxicity of RNases. Notomista et al. [19] proposed that cytotoxic RNases must possess specific electrostatic features and structural elements serving for the interaction with cellular membranes, conceivably located at the $\mathrm{N}$-terminal region of the molecule. The cluster of positively charged Lys $(1,3,111,112)$ residues, located at the flexible coil near the N-terminus, is critical for the bactericidal activity of human RNase7 [20, 21]. Main contribution to the toxicity of the eosinophil cationic protein is made by a region located at the protein $\mathrm{N}$-terminus, residues 1135 [22]. The variant of bovine seminal RNase (BSRNase), G38K-BSRNase, carrying enhanced cluster of positive charges at the $\mathrm{N}$-terminus surface, possesses an increased cytotoxicity toward tumor cells [23]. However, cationization of the N-terminus of RNase $\mathrm{Sa}\left(\mathrm{K}_{2}{ }^{\mathrm{N}} \mathrm{Sa}\right)$ and the charge neutralization mutant ( $\mathrm{K}_{2}{ }^{\mathrm{N}} 5 \mathrm{NQ} \mathrm{Sa}$ ) appeared to be ineffective (Fig. 3). It should be noted that cytotoxicity of the $3 \mathrm{~K} \mathrm{Sa}$ is virtually identical to cytotoxicity of $\mathrm{K}_{2}{ }^{\mathrm{N}} 5 \mathrm{NQ} \mathrm{Sa}$ (Figs. 1,3), although the charge of the first mutant is negative (net charge -1), while for the second mutant it is neutral (net charge 0 ). Further, the $6 \mathrm{~K}$ mutant had even stronger effect on the survival rate and apoptosis induction in the Kasumi-1 cells compared to the mutant $\mathrm{K}_{2}{ }^{\mathrm{N}} 5 \mathrm{~K}$ Sa with similar net charge (+5) (Figs. 1-3). These results suggest that an important factor defining the RNase Sa cytotoxicity is the distribution of positive charge on the molecular surface rather than its localization on the
$\mathrm{N}$-terminus. This is confirmed by the evidence that cytotoxicity of the RNase Sa mutants with substitutions of residues located on molecular surface and of the Lystagged variants fits linear curve against the molecular charge (Fig. 1B).

The mechanism of antitumor activity of exogenous RNase remains largely unclear, but the contribution of positive charge of the molecule to RNase-induced cell death is beyond doubt $[2,3]$. Cationization of RNases using chemical agents is a common approach to enhancing their cytotoxicity. However, to separate cytotoxic effects of the actual RNases from the effects of associated polycations, the latter should not constitute a significant part of the chimeric molecule. The set of RNase Sa mutants and their variants with the $\mathrm{N}$-terminal extension developed by us, allowed to clarify the role of positive net charge and its molecular distribution in cytotoxicity. Here we have shown that cytotoxic properties of these RNases increase linearly with the net charge growth, and that the charge localization on the N-terminus does not provide additional contribution to the cytotoxicity. Cytotoxicity of the RNase Sa mutants to Kasumi-1 cells is caused by their apoptosis-inducing effect, which allows to consider them as potential anti-cancer agents along with other RNases.

\section{METHODS}

\section{Proteins}

RNase $\mathrm{Sa}$ and the mutants listed above were prepared, expressed, and purified as described previously $[15,24]$.

\section{Catalytic activity}

Catalytic activity was determined for the poly(I) hydrolysis at $25^{\circ} \mathrm{C}$, as described in [14]. The initial rates were measured by recording the change in absorbance at $248 \mathrm{~nm}$. The buffer used was $0.05 \mathrm{M}$ Tris, $0.1 \mathrm{M}$ sodium chloride, and $0.05 \mathrm{M}$ sodium acetate, $\mathrm{pH}$ 6.5. Concentrations of RNase $\mathrm{Sa}$ and its mutants were determined spectrophotometrically using the same molar extinction coefficient $\varepsilon_{278}=12300 \mathrm{M}^{-1} \mathrm{~cm}^{-1}$ [25].

\section{Cell culture}

Human acute myeloid leukemia cells Kasumi-1, obtained from the Heinrich-Pette Institute Leibniz Institute for Experimental Virology (Hamburg, Germany), were used. Kasumi-1 cells were grown on RPMI-1640 media containing $20 \%$ FCS, 100 units $/ \mathrm{ml}$ penicillin, $100 \mu \mathrm{g} /$ $\mathrm{ml}$ streptomycin, and $1 \mathrm{mM}$ sodium pyruvate at $37^{\circ} \mathrm{C}$ in humid atmosphere with $5 \% \mathrm{CO}_{2}$. 


\section{Cell Viability}

Cellular viability was assessed with a WST-1-based test (Roche Diagnostics) as described earlier [11]. The cells were plated into 96 -well plates $\left(3 \times 10^{4}\right.$ cells per well) and cultured for $24 \mathrm{~h}$ at $37^{\circ} \mathrm{C}$. Then the cells were treated with binase. After $72 \mathrm{~h}$ of the binase treatment the cells were incubated with the WST-1 reagent for 60 min at $37^{\circ} \mathrm{C}$. The absorbance of samples was measured with an Anthos 2020 microplate reader (Anthos Labtech Instruments $\mathrm{GmbH}$ ) at $450 \mathrm{~nm}$. The reference wavelength was $620 \mathrm{~nm}$. A mixture of cell-free medium with the WST1 reagent was used as a background control. The viability of untreated cells was taken as $100 \%$. All reported values are means of three independent measurements with triplicate samples \pm standard deviations.

\section{Determination of the amounts of apoptotic and necrotic cells by flow cytometry}

Apoptotic and necrotic cells in population were determined by double staining with Annexin V-FITC (Molecular Probes) [26] and propidium iodide (PI) (Sigma) [27]. Annexin positive cells considered as apoptotic while PI positive Annexin negative cells considered as necrotic. All measurements were carried out on a GALLIOS flow cytometer (Beckman Coulter).

\section{Statistical analysis}

Values are shown as means \pm standard deviations. The comparison of data groups was performed using Student's t-test; $\mathrm{p}<0.05$ was considered significant.

\section{ACKNOWLEDGEMENTS}

This work was supported by the Fundamental Research for Biomedical Technologies and Molecular and Cellular Biology Programs of the Russian Academy of Sciences, by grant from the Russian Foundation for Basic Research (14-04-00798-a), by ICGEB (grant CRP/RUS1102) and by the Ministry of Education and Science of the Russian Federation under state contract 14.621.21.0001 (part of this work was performed at the EIMB RAS "Genome" center, http://www.eimb.ru/RUSSIAN_NEW/ INSTITUTE/ccu_genome_c.php).

\section{Conflict of intrests}

The author declare no conflict of intrests.

\section{Abbreviations}

RNase Sa, ribonuclease from Streptomyces aureofaciens; BS-RNase, bovine seminal RNase

\section{REFERENCES}

1. Ardelt W, Ardelt B and Darzynkiewicz Z. Ribonucleases as potential modalities in anticancer therapy. Eur J Pharmacol. 2009; 625:181-189.

2. Fang EF and Ng TB. Ribonucleases of different origins with a wide spectrum of medicinal applications. Biochim Biophys Acta. 2011; 1815:65-74.

3. Makarov AA, Kolchinsky A and Ilinskaya ON. Binase and other microbial RNases as potential anticancer agents. BioEssays. 2008; 30:781-790.

4. Ran S, Downes A and Thorpe PE. Increased exposure of anionic phospholipids on the surface of tumor blood vessels. Cancer Res. 2002; 62:6132-6140.

5. Makarov AA and Ilinskaya ON. Cytotoxic ribonucleases: molecular weapons and their targets. FEBS Lett 2003; 540:15-20.

6. Lomax JE, Eller $\mathrm{CH}$ and Raines RT. Rational design and evaluation of mammalian ribonuclease cytotoxins. Methods in Enzymology. 2012; 502:273-290.

7. Ellis GA, Hornung ML and Raines RT. Potentiation of ribonuclease cytotoxicity by a poly(amidoamine) dendrimer. Bioorg Med Chem Lett. 2011; 21:2756-2758.

8. Ilinskaya ON, Dreyer F, Mitkevich VA, Shaw KL, Pace CN and Makarov AA. Changing the net charge from negative to positive makes ribonuclease Sa cytotoxic. Protein Sci. 2002; 11:2522-2525.

9. Ilinskaya ON, Koschinski A, Mitkevich VA, Repp H, Dreyer F, Pace CN and Makarov AA. Cytotoxicity of RNases is increased by cationization and counteracted by $\mathrm{KCa}$ channels. Biochem Biophys Res Commun. 2004; 314:550-554.

10. Turcotte RF, Lavis LD and Raines RT. Onconase cytotoxicity relies on the distribution of its positive charge. FEBS J. 2009; 276:3846-3857.

11. Mitkevich VA, Petrushanko IY, Spirin PV, Fedorova TV, Kretova OV, Tchurikov NA, Prassolov VS, Ilinskaya ON and Makarov AA. Sensitivity of acute myeloid leukemia Kasumi-1 cells to binase toxic action depends on the expression of KIT and AML1-ETO oncogenes. Cell Cycle. 2011; 10:4090-4097.

12. Mitkevich VA, Kretova OV, Petrushanko IY, Burnysheva KM, Sosin DV, Simonenko OV, Ilinskaya ON, Tchurikov NA and Makarov AA. Ribonuclease binase apoptotic signature in leukemic Kasumi-1 cells. Biochimie. 2013; 95:1344-1349.

13. Knowles JR. Tinkering with enzymes: what are we learning? Science. 1987; 236:1252-1258.

14. Yakovlev GI, Mitkevich VA, Shaw KL, Trevino S, Newsom 
S, Pace CN and Makarov AA. Contribution of active site residues to the activity and thermal stability of ribonuclease Sa. Protein Sci. 2003; 12:2367-2373.

15. Trevino SR, Gokulan K, Newsom S, Thurlkill RL, Shaw KL, Mitkevich VA, Makarov AA, Sacchettini JC, Scholtz $\mathrm{JM}$ and Pace CN. Asp79 makes a large, unfavorable contribution to the stability of RNase Sa. J Mol Biol. 2005; 354:967-978.

16. Szachowicz-Petelska B, Dobrzyńska I, Skrodzka M, Darewicz B, Figaszewski ZA and Kudelski J. Phospholipid composition and electric charge in healthy and cancerous parts of human kidneys. J Membr Biol. 2013; 246(5):421425.

17. Futami J, Nukui E, Maeda T, Kosaka M, Tada H, Seno $\mathrm{M}$ and Yamada H. Optimum modification for the highest cytotoxicity of cationized ribonuclease. J Biochem. 2002; 132:223-228.

18. Futami J and Yamada H. Design of cytotoxic ribonucleases by cationization to enhance intracellular protein delivery. Curr Pharm Biotechnol. 2008; 9:180-184.

19. Notomista E, Mancheno JM, Crescenzi O, Di Donato A, Gavilanes $\mathrm{J}$ and D'Alessio $\mathrm{G}$. The role of electrostatic interactions in the antitumor activity of dimeric RNases. FEBS J. 2006; 273(16):3687-3697.

20. Huang YC, Lin YM, Chang TW, Wu SJ, Lee YS, Chang $\mathrm{MD}, \mathrm{Chen} \mathrm{C}, \mathrm{Wu} \mathrm{SH}$ and Liao YD. The flexible and clustered lysine residues of human ribonuclease 7 are critical for membrane permeability and antimicrobial activity. J Biol Chem. 2007; 282(7):4626-4633.

21. Wang H, Schwaderer AL, Kline J, Spencer JD, Kline D and Hains DS. Contribution of structural domains to the activity of ribonuclease 7 against uropathogenic bacteria. Antimicrob Agents Chemother. 2013; 57:766-774.

22. Sánchez D, Moussaoui M, Carreras E, Torrent M, Nogués $\mathrm{V}$ and Boix E. Mapping the eosinophil cationic protein antimicrobial activity by chemical and enzymatic cleavage. Biochimie. 2011; 93:331-338.

23. D'Errico G, Ercole C, Lista M, Pizzo E, Falanga A, Galdiero $\mathrm{S}$, Spadaccini R and Picone D. Enforcing the positive charge of $\mathrm{N}$-termini enhances membrane interaction and antitumor activity of bovine seminal ribonuclease. Biochim Biophys Acta. 2011; 1808:3007-3015.

24. Shaw KL, Grimsley GR, Yakovlev GI, Makarov AA and Pace CN. The effect of net charge on the solubility, activity, and stability of ribonuclease Sa. Protein Sci. 2001; 10:12061215 .

25. Hebert EJ, Grimsley GR, Hartley RW, Horn G, Schell D, Garcia S, Both V, Sevcik J and Pace CN. Purification of ribonucleases $\mathrm{Sa}, \mathrm{Sa} 2$, and $\mathrm{Sa} 3$ after expression in Escherichia coli. Protein Express Purificat 1997; 11:162168.

26. Koopman BG, Reutelingsperger CPM, Kuijten GAM, Keehnen RMJ, Pals ST and van Oers MHJ. Annexin V for flow cytometric detection of phosphatidylserine expression on B cells undergoing apoptosis. Blood 1994; 84:14151420 .

27. Riccardi C and Nicoletti I. Analysis of apoptosis by propidium iodide staining and flow cytometry. Nat Protoc. 2006; 1:1458-1461. 